\title{
The rise and fall of dietetics and of nutrition science, 4000 BCE-2000 CE
}

\author{
Geoffrey Cannon* \\ World Health Policy Forum, Juiz de Fora, Brazil
}

\begin{abstract}
Objective: To outline the history of dietetics since its beginnings in recorded history, and of nutrition science in its first phase beginning in the mid-nineteenth century and then its second phase in the second half of the twentieth century.

Method: Three narrative overviews: of dietetics from its beginnings until after the end of the mediaeval and then Renaissance periods in Europe; of nutrition science in its first phase from its beginnings in the mid-nineteenth century until the middle of the twentieth century, with reasons for its rise; and of nutrition science in its second phase in the second half of the twentieth century, with reasons for its decline.

Conclusions: In its third phase in the twenty-first century, the new nutrition science should regain much of the vision and scope of its preceding disciplines.
\end{abstract}

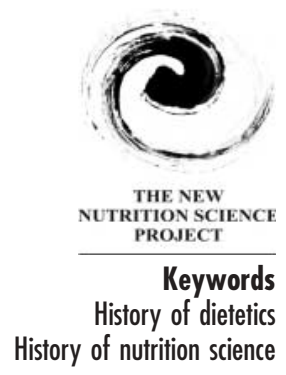

\section{BCE-1850 CE. The fulfilled life}

The first known teachings on nutrition and health are African. The Egyptian Imhotep gave accounts of the use of food as medicine about 6000 years ago ${ }^{1}$. Traditional Chinese teachings from those of the 'Yellow' Emperor Huang Ti around $2500 \mathrm{BCE}$, and of the Indian Ayurvedic tradition, also stress the importance of specified dietary patterns, foods and drinks, and plants with medicinal qualities, to prevent and treat disease and also as ways to a spiritually, morally, emotionally and mentally enlightened life ${ }^{2}$.

From the beginnings of recorded history and in Europe up to and beyond the mediaeval era, teaching and practice on food, nutrition and health have been deep and broad. In what is now Europe, Pythagoras, Heraclitus, Alcmaeon, Hippocrates, Celsus, Dioscorides, Plotinus, Pliny the Elder, Plutarch and Porphyry, as well as other Greek, Roman and other philosophers, physicians and teachers who laid foundations for Western science and medicine, developed inductive and deductive systems of thinking about food and health between 600 BCE and 300 CE. The flowering of Arab culture between the eighth and the twelfth centuries CE included comparable teachings of Rhazes, Ibn Botlân, Ibn Sina Abu Ali Al Husain (Avicenna) and Moses Maimonides, Jewish physician to Salah al-Din (Saladin); these also became synthesised in 'The Regime of Health' treatise of the first major medical school in Europe at Salerno, published as from $1100 \mathrm{CE}$ and one of the first books to be printed ${ }^{2,3}$.

Originally ancient philosophies of the fulfilled life, of which teachings on diet and nutrition are an integral part, persisted in Europe through the Renaissance period and up to the period of the 'Enlightenment' of the eighteenth century ${ }^{4}$. Indeed, they still persist in many parts of the world, as do those of oral societies that have developed systematised concepts of food and nutrition within natural environments. The Greek term diaita means 'way of life' or 'way of being', and the term 'diet' was used in this sense in treatises and handbooks until recent times in Europe. Human health and welfare are seen ecologically, in the context of the whole living and physical world, the 'great chain of being, ${ }^{5}$. Their written records resonate with some of the writings now found in the 'healing and nutrition' sections of bookstores and 'wholefood' emporiums ${ }^{6,7}$.

\section{0-1950 CE. The bigger the better}

In post-mediaeval and Renaissance Europe, and then in the USA and other technologically developing countries, human beings and all other living things became identified as marvellous machines, by analogy with clocks, pumps, trains, or other forms of engineering. Study of life itself, and of consciousness and vitality, became seen as metaphysical. Aspects of humanity other than the physical were excluded by the rising sciences, within the context of a dominant ideology based on principles of political and economic power and growth.

Science was used to master nature. Massive machines and men have been better able to create material wealth, exploit the living and physical world, defeat other powerful nations, and dominate less technically developed peoples. Anything that moves faster and grows bigger was identified for this reason as better - and healthier. Scientists interested in the ways of nature and in what it means to be alive were 
Nutrition scientists have taken a deep or broad view of their work and its implications since the beginnings of the discipline in the early nineteenth century; as have their predecessors, whose teachings and writings laid the foundations of dietetics as an empirical discipline. In the first years of the twenty-first century, the original vision and scope of nutrition science and of food and nutrition policy are being revived.

dismissed as 'vitalists' and 'nature philosophers' and such terms became phrases of abuse ${ }^{8}$.

Nutrition science in its modern form dates from the early to mid-nineteenth century; it had the effect of creating dietetics as a separate paramedical profession?. The first generations of physiologists, biochemists and physicians who created nutrition science along the lines of the disciplines in which they were trained, believed they could change the world. So they did, once governments and industry endorsed their ideas. The dimensions of nutrition narrowed but its scope widened. It became less a philosophy of life, more an instrument of state.

\section{Chemistry and revolution}

The German chemist Justus von Liebig, building on the work of Antoine Lavoisier, François Magendie, Jöns Berzelius, William Prout, Gerrit Mulder and others, who worked most of his productive life in Giessen, was a founder of biochemistry, and was the founder of nutrition as a biochemical science. His stamp on public affairs is comparable with that of Louis Pasteur in the field of microbiology. Both men possessed astounding energy, both courted the ruling classes; both smashed the reputations of fellow scientists whose views were holistic and ecological; and both facilitated the supremacy of current conventional science and practice ${ }^{8,10,11}$.

Emerged from its alchemical origins, chemistry became the rising science, and nutrition a biochemical discipline, because von Liebig and his followers realised that physiological chemistry (as it was at first termed) could be used to harness and master nature and to engineer the food systems of industrialising countries. Von Liebig grasped the significance of protein as the chemical compound that accelerates the early growth of plants, animals and humans. Once protein was isolated and identified as the primary or master nutrient and so the nutritional expression of the dominant European ideology, food systems engineered to emphasise animal protein had the power to change the world, as they have done $^{8,12}$.

The science of nutrition in its first period, roughly between 1850 and 1950, was harnessed by governments of the great European powers and the USA to increase the yield of food from plants and animals, and to build up their human resources, when more and more factory workers and foot soldiers were needed to increase national advantage and to service industrialisation and imperialism.
In the most powerful European countries, philanthropists and politicians were united in their interest in nutrition. Both were preoccupied with the condition of the poor, partly for fear of uprisings of enraged ideologues and under-classes. 'Many have died of starvation, where long-continued want of proper nourishment has called forth fatal illness, when it has produced such debility that causes which might otherwise have remained inoperative brought on severe illness and death. The English working class men call this "social murder"'. This is Friedrich Engels writing in the mid-1840s ${ }^{13}$; in 1848 he and Karl Marx were in Germany fomenting the revolutions that swept through continental Europe ${ }^{14}$.

It was then that von Liebig and his followers throughout Europe and then the USA blazoned chemistry as the solution for plant, animal and human breeding, and even as containing the secrets of life itself. This was the time when the priorities of chemical nutrition ceased to be conceptual and experimental, and became dictated by social, economic and political factors ${ }^{8}$. Its prescription was protein of animal origin. 'A vastly more important question than even the victualling of the navy... is that of victualling of the masses at home', wrote a British commentator ${ }^{15}$. 'What is at the moment deteriorating the lower stratum of the population? - the want of a sufficient supply of nitrogenous food... why should we not have meat too?'

\section{Food security and war}

Nutrition science was in the big time. Its teaching and practice were at first dominated by Britain and Germany, and later by the USA and Britain. Half the economic growth in the UK and other Western European countries between 1790 and 1980 is attributed to improvements in population nutrition, together with other public health measures such as proper sanitation ${ }^{16}$. Its impetus continued, with early twentieth century experiments identifying a series of diseases whose usual fundamental cause is deprivation and destitution as vitamin-deficiency diseases. In the USA, following Wilbur Atwater's work on energy and protein, Elmer McCollum and others established 'the newer knowledge of nutrition'. In Britain, the prescriptions of John Boyd Orr, Jack Drummond, Hugh Sinclair and others were adopted by government as an essential part of the 1939-1945 war effort, and the national food system was engineered so as to become more nourishing ${ }^{4,12}$. 
Boyd Orr, the most eminent founder of public health nutrition, was the first director-general of the Food and Agriculture Organization of the United Nations (UN) and to date the last nutrition scientist to be a Nobel laureate - a Peace Prize for his work advocating equity of world food supplies. While trained as a physician and physiologist, he embraced the environmental, social, economic, political, ethical and human rights dimensions of nutrition, and pressed its importance on policy-makers and in the media spotlight $^{17}$.

Boyd Orr had an impact on national public policy in Britain in the 1930s and 1940s comparable with that of von Liebig in the previous century. His proposals were built into programmes celebrated by Peter Medawar as 'the best single example known to me of synergy between science and government ${ }^{18}$, which controlled and shaped the British food supply during the 1939-1945 war, and were a factor in its outcome.

Thus, between the mid-nineteenth and the midtwentieth centuries, nutrition in its biochemical aspect became applied as part of central government policies in Europe and North America. The overall objectives of successive governments were internal social security, competitive advantage over other industrialised nations, and world domination. Consequent food and nutrition policies included legal, fiscal, regulatory and other methods affecting price, availability and quality. They worked.

\section{0-2000 CE. Decline and fall}

In the second half of the twentieth century the genie of nutrition was put back in the bottle. External forces some global, others with special effect in the USA, the UK and their spheres of influence - made the theory and practice of nutrition less significant and more specialist, and nutrition scientists less confident and more defensive. The thrill had gone.

These forces and others explain the paradoxical waning importance of nutrition in a period when it became evident that food and nutrition modifies the risk of those chronic diseases that are now the major immediate causes of premature disability and death throughout the world $^{19,20}$. Many of these forces do not apply only to the science of nutrition and to nutrition and food policy. They can be identified under the headings of complacency, oligarchy, cacophony, technocracy and ideology.

\section{Complacency}

\section{1. 'Conquest' of nutritional deficiencies}

After the 1939-1945 World War it was generally agreed that human nutrition was no longer a subject worth serious scientific attention. Jack Drummond wrote: 'There is no problem of nutrition in Britain today... The position is perfectly clear-cut' ${ }^{4}$. Donald Acheson, who in the 1980s as Chief Medical Officer controlled UK official nutrition policy committees, said when he was a medical student in the late 1940s: 'There were no remaining problems in human nutrition... All that was necessary was to eat a good mixed diet. . avoid obesity and all would be well ${ }^{21}$. Problems of food insecurity and nutritional deficiency remained front-rank public health priorities for much of the world, but these were seen mostly as mundane issues of food supply, emergency aid or clinical intervention.

\section{2. 'Conquest' of infectious diseases}

Coincidentally, antibacterial drugs were first manufactured on a mass scale in the 1939-1945 war. In the 1950 s and 1960s the first generations of antibiotics proved successful treatment for many transmissible diseases, and so seemed to prove the 'germ theory' of Louis Pasteur, Paul Ehrlich and others: not only that most (if not all) diseases are caused by microbes, but also that they can be cured by antimicrobial drugs. In the professional and lay mind diseases have become confused with external agents, needing aggressive intervention with pharmaceuticals administered by physicians ${ }^{22}$. The discovery of the therapeutic power of antimicrobials, and thus the spectacular growth of the pharmaceutical industry, has led to the ascendancy of modern medicine and therefore to the decline of public health and of social and environmental aspects of nutrition.

\section{Oligarchy}

\section{Maintenance of government control}

Between 1939 and 1945 democracy was modified or suspended in those countries fighting a war of national survival. National food supplies were shaped by government-appointed committees of civil servants, industrialists and scientists whose main task was to increase production and ensure food and nutrition security. Having got into the habit of secretive policy-making, the UK government maintained this closed committee system into the 1970s; and perhaps because of the freak chance that Margaret Thatcher was an industrial food chemist by training (having devised cake fillings before she entered politics) also throughout the 1980s. Many senior nutrition scientists advised government, subject to the Official Secrets Act. If they attempted to question any aspect of the national food system, their findings were ignored, overturned, suppressed or denounced ${ }^{23-26}$.

\section{International agency unaccountability}

The victorious nations who controlled the newly formed UN specified that its policies on food and nutrition should focus on increased industrialisation and production of food in rich countries; and programmes whose stated purpose was to achieve food security and to control and treat nutritional deficiencies in poor countries. Until the 1990s the UN system was unresponsive to the evidence causally linking inappropriate food and nutrition to major chronic diseases ${ }^{27}$. Remoteness of the UN agencies is as 
nothing compared with that of the World Bank, the International Monetary Fund and the World Trade Organization, whose policies and programmes, which increasingly shape global food systems, are commonly seen as an extension of the foreign and trade policies of the most powerful nations ${ }^{28}$.

\section{Cacophony}

\section{Unexplained policy U-turns}

In the 1950s and 1960s it was said that fat should 'provide at least 25 per cent of the calorie value of the diet' and 'it is appropriate to increase this proportion to about 35 per cent $^{29,30}$. From the 1960 s the recommendation went from more to less: consumption of fat should be cut to $30 \%$ or $30-35 \%$ of calories, and from 1990 on a global basis to $15-$ $30 \%$ of calories ${ }^{19,20,31}$. The explanation, that the shift reflected changed priorities from prevention of deficiencies to prevention of obesity and heart disease, was never successfully communicated to politicians or the public. Also demoralising to the profession was the 'great protein fiasco': the massive recalculation of human protein requirements in the 1970s which 'at the stroke of a pen' closed the 'protein gap' and destroyed the theory of pandemic 'protein malnutrition' 32 .

\section{Marketing and advertising babble}

The spend on marketing and advertising of the largest food and drink manufacturers, most of whose lead products have nutritional profiles generally agreed to be unhealthy, continues to increase exponentially. The global spend of Coca-Cola and also of McDonald's was recently calculated to be \$US 1.4 billion a year ${ }^{33}$. Many manufacturers' messages conflict with others, and also with those of food retailers, and most conflict with the findings of nutrition science. Nutrition advice has been distorted by trade groups protecting the interests of milk, baked goods, soft drinks, sugar and salt, with massive budgets spent on lobbying legislators; and also by national and global nutrition foundations controlled or influenced by those sectors of industry whose products are energydense, high in fat, sugar and/or salt ${ }^{34}$.

\section{Technocracy}

\section{Accelerating specialism}

From postgraduate to Nobel laureate, scientists are expected to undertake and publish original work. What this means is an exponential increase of more and more specialist research and journals. Nutrition scientists are not trained to see much of the context of their work and few can find the time to do so. Much research is minutely detailed, and a considerable fraction, especially in sensitive areas, is funded defensively by interested parties such as sectors of the food industry. The recent drive originating in the USA to give pre-eminent credibility to the results of randomised controlled trials, a type of study whose main use is to test the efficacy of drugs ${ }^{35,36}$, would if generally accepted have the effect of vitiating most epidemiological and experimental studies designed to establish causal relationships between food and nutrition, and health and disease.

\section{Corralling of science}

Ever since the establishment of 'Big Science' in the USA to serve what President Eisenhower called 'the militaryindustrial complex', the scientific enterprise has become increasingly interdependent with government and industry, in general ${ }^{37,38}$ and in the biological sciences, including nutrition $^{39,40}$. Research scientists are now mostly dependent on funding from government and its agencies as well as from industry; and research institutes supported by public money are graded by ability to raise funds from industry. When such funding comes with expectations of a result favourable to the funder's policies, science is degraded and scientists demoralised. Scientists respond to such systematic pressure either by becoming detached from policy, or else by choosing to court government and industry funding.

\section{Ideology}

\section{Let the consumer beware}

The laissez-faire ideology dominant since the 1980s is hostile to legal, fiscal and regulatory intervention in the public interest and to admission that food, nutrition and disease patterns have social, economic and political causes. Governments have withdrawn from public health, resist interventions designed to improve food systems, and mostly confine food and nutrition policies to information and education on prudent 'lifestyle'. Industry now lists some chemical constituents of processed food on standardised 'nutrition' labels ${ }^{12}$. The approach generally adopted by governments is strikingly different from those for control of smoking of tobacco and drinking of alcohol, whose supply and demand are modified by taxation of price and regulation of advertising and marketing.

\section{Band aid}

UN agency programmes designed to eliminate food insecurity and deficiency diseases and achieve 'health for all' can be developed, maintained and sustained only if dominant nations are genuinely determined to address the fundamental causes of deprivation and disease. Instead, as dedicated officials within the UN system know and sometimes acknowledge, inequalities between and within high- and low-income countries are widening ${ }^{41}$, and the wealthiest nations continue to use food trade and aid in order to create increased dependency and indebtedness in the South ${ }^{42,43}$. Aid agencies distribute, sell and promote food of minimum nutritional standard as famine relief, and together with UN agencies distribute and promote 
nutritional supplements and foods 'fortified' with vitamins and minerals in poor countries.

\section{Conclusion}

Nutrition scientists have taken a deep or broad view of the scope of their work and its implications since the beginnings of the discipline in modern form in the early nineteenth century; as have their predecessors whose teachings and writings laid the foundations of dietetics as an empirical discipline, and thence nutrition as a modern science.

The scope of conventional nutrition in its second phase in the second half of the twentieth century has been reduced and confined. This decline should be seen as historical, albeit not yet defunct.

\section{References}

1 Darby W, Ghaliongi P, Grivettill P. Food, the Gift of Osiris. London: Academic Press, 1977.

2 Estes J. Food as medicine. In: Kiple K, Ornelas K, eds. The Cambridge World History of Food. Cambridge: University Press, 2000.

3 Hutchison R. The history of dietetics. In: Mottram V, Graham G, eds. Hutchison's Food and the Principles of Dietetics, 9th ed. London: Edward Arnold, 1944 [originally published in The Practitioner, January 1934].

4 Drummond J, Wilbraham A. The Englishman's Food. Five Centuries of English Diet. London: Pimlico, 1991 [first published in London: Jonathan Cape, 1939].

5 Lovejoy A. The Great Chain of Being. Cambridge, MA: Harvard University Press, 2001 [originally published 1936].

6 Schmid R. Traditional Foods Are Your Best Medicine. New York: Ballantine, 1987.

7 Robbins R. The Food Revolution. How Your Diet Can Help Save Your Life and the World. Boston, MA: Conari, 2001.

8 Brock W. Justus von Liebig. The Chemical Gatekeeper. Cambridge: University Press, 1997.

9 Beaudry M. Think globally, act locally. Do dietitians have a role to play in alleviating hunger in the world? Journal of Canadian Dietetic Association 1985; 46(1): 19-27.

10 Kirschke M. Liebig, his university professor Karl Wilhelm Gottlob Kastner (1783-1857) and his problematic relation with romantic natural philosophy. Ambix 2003; 50(1): 3-24.

11 Latour B. War and peace of microbes [Part One]. In: The Pasteurization of France. Cambridge, MA: Harvard University Press, 1988 [first published in Paris: Editions Métailié, 1984].

12 Cannon G. The Fate of Nations. London: Caroline Walker Trust, 2003. Obtainable from the author at geoffreycannon@ aol.com

13 Engels F. The Condition of the Working Class in England. London: Penguin, 1987 [originally published in German, 1845].

14 Hobsbawm E. Revolutionary prelude [Part 1]. In: The Age of Capital: 1848-1875. London: Abacus, 2003 [originally published in London: Weidenfeld and Nicolson, 1975].

15 Wynter A. Our Social Bees. London:, 1861.

16 Fogel R. Economic growth, population theory and physiology: the bearing of long-term processes on the making of economic policy. American Economic Review 1994; 84: 369-95.

17 Orr J. Foreword to second edition. In: Food Health and Income. London: Macmillan, 1937.
18 Medawar P. An essay on scians. In: The Limits of Science. Oxford: University Press, 1985.

19 Cannon G. Food and Health: The Experts Agree. London: Consumers' Association, 1993.

20 World Health Organization (WHO). Diet, Nutrition and the Prevention of Chronic Diseases. Report of a Joint WHO/Food and Agriculture Organization Expert Consultation. Technical Report Series No. 916. Geneva: WHO, 2003.

21 Acheson D. Food policy, nutrition and government [10th Boyd Orr lecture]. Proceedings of the Nutrition Society 1986; 45: 131-8.

22 Cannon G. Unconquered epidemics [Chapter 3]. In: Superbug. London: Virgin, 1995.

23 Smith D. A case of Parturiunt Montes, Nascitur Ridiculus Mus? The BMA nutrition committee 1947-1950 and the political disengagement of nutrition science. Journal of the History of Medicine and Allied Sciences 2004; 59(2): 240-72.

24 Walker C, Cannon G. The story of the food scandal. In: The Food Scandal, enlarged paperback ed. London: Century, 1985.

25 Cannon G. Science, government and industry. The system [Chapter 6]. In: The Politics of Food. London: Century, 1987.

26 Lacey R. Mad Cow Disease. The History of BSE in Britain. Jersey: Cypsela, 1994.

27 Food and Agriculture Organization of the United Nations (FAO)/World Health Organization. International Conference on Nutrition. World Declaration and Plan of Action. Rome: FAO, 1992.

28 Stiglitz J. Broken promises [Chapter 2]. In: Globalization and Its Discontents. London: Allen, 2002.

29 British Medical Association (BMA). Report of the Committee on Nutrition. London: BMA, 1950.

30 Ministry of Agriculture, Fisheries and Food. Manual of Nutrition, 6th ed. London: HMSO, 1961 [reprinted 1966].

31 World Health Organization (WHO). Diet, Nutrition and the Prevention of Chronic Diseases. Report of a WHO Study Group. Technical Report Series No. 797. Geneva: WHO, 1990.

32 McLaren D. The great protein fiasco. Lancet 1974; ii: 93-6.

33 Lang T. Food industrialization and food power: implications for food governance. Development Policy Review 2003; 21(5): $555-68$.

34 Cannon G. Why the Bush administration and the global sugar industry are determined to demolish the 2004 WHO global strategy on diet, physical activity and health. Public Health Nutrition 2004; 7(3): 369-80.

35 National Institutes of Health (NIH). Clinical Guidelines for the Identification, Evaluation and Treatment of Overweight and Obesity in Adults: The Evidence Report. NIH Publication, 98-4083. Washington, DC: NIH, 1998.

36 US Department of Health and Human Services, Office of Global Health Affairs. Letter to the Directors-General of WHO and FAO, received 5 January 2005 [unpublished].

37 Fuller S. The pilgrimage from Plato to Nato [Chapter 1]. In: Thomas Kubn. A Philosophical History for Our Times. Chicago, IL: University Press, 2000.

38 Bok D. Scientific research [Chapter 5]. In: Universities in the Marketplace. The Commercialization of Higher Education. Princeton, NJ: University Press, 2003.

39 Proctor S. Cancer Wars. How Politics Shapes What We Know and Don't Know about Cancer. New York: Basic Books, 1995.

40 Nestle M. Working the system [Part 2]. In: Food Politics. How the Food Industry Influences Nutrition and Health. Berkeley, CA: University of California Press, 2002.

41 Shrimpton R. Evidence v. rights-based decision making for nutrition. Proceedings of the Nutrition Society 2003; 62: 553-62.

42 George S. How the Other Half Dies. The Real Reasons for World Hunger. London: Penguin, 1975.

43 Oxfam. Rigged Rules and Double Standards. Trade, Globalization and the Fight against Poverty. Oxford: Oxfam, 2002. 